\title{
Adsorption of human serum albumin onto gold: a combined electrochemical and ellipsometric study
}

\author{
Peiqing Ying ${ }^{\mathrm{a}}$, Ana S. Viana ${ }^{\mathrm{b}}$, Luisa M. Abrantes ${ }^{\mathrm{b}, \mathrm{c}}$, Gang Jin ${ }^{\mathrm{a}, *}$ \\ a Institute of Mechanics, Chinese Academy of Sciences, Beijing 100080, China \\ ${ }^{\mathrm{b}}$ Lab of SPM, Faculdade de Ciências, Universidade de Lisboa, Campo Grande, 1749-016 Lisbon, Portugal \\ ${ }^{c}$ Departamento de Química e Bioquímica, Faculdade de Ciências, Universidade de Lisboa, Campo Grande, 1749-016 Lisbon, Portugal
}

Received 14 January 2004; accepted 17 June 2004

Available online 24 July 2004

\begin{abstract}
Human serum albumin adsorption onto gold surfaces was investigated by electrochemical and ellipsometric methods. Albumin adsorption onto gold was confirmed by the change of the open circuit potential of gold and by the ellipsometric parameter variation during albumin immobilization. In both experiments the parameters reached stable values within 10-15 min. The albumin adsorption layer thickness measured with the ellipsometer was about $1.5 \mathrm{~nm}$. The adsorption of albumin under applied potential was also investigated and it was found that both positive and negative applied potential promote albumin adsorption. Changes in the optical parameters of bare gold and albumin adsorbed onto gold surface under applied potential were investigated with in situ ellipsometry. The similarity and reversibility of the optical changes showed that adsorbed albumin was stable on the gold surface under the applied potential range (-200-600 mV). The cyclic voltammograms of $\mathrm{K}_{3} \mathrm{Fe}(\mathrm{CN})_{6}$ on the modified gold surface showed that albumin could partly block the oxidation and reduction reaction.
\end{abstract}

(c) 2004 Elsevier Inc. All rights reserved.

Keywords: Human serum albumin; Adsorption; Gold; Electrochemistry; Ellipsometry

\section{Introduction}

Protein adsorption or immobilization on solid surfaces is important in many areas including immunoassays and biosensors where protein-protein interaction is established. Adsorption of serum proteins onto surfaces also plays a key role in biomaterial design because of the change of material properties of the adsorbed proteins [1-5]. In either case, the properties of the protein-substrate system will critically depend on the surface concentration (or the adsorption layer thickness), the conformation, and the surface coverage of the protein. Many investigations have been carried out regarding protein-metal interaction [6-10]. Protein adsorption onto metal surfaces is the initial important event that occurs on implanted metal; the nature of protein adsorption will in-

\footnotetext{
* Corresponding author. Fax: +86-10-62561284.

E-mail address: gajin@imech.ac.cn (G. Jin).
}

fluence the subsequent tissue response on the metal [9]. Protein adsorption on metal surfaces is also important in food processing and in environmental inspecting where metal is in contact with protein solutions.

Many kinds of methods are used to study protein adsorption on surfaces, such as ellipsometry [11-14], variable angle reflectometry [15,16], fluorescence spectroscopy [17], and atomic force microscopy [18]. Among these, ellipsometry is a nondestructive, optical-surface-sensitive method for the investigation of protein adsorption mainly at metal surfaces [12]. Ivarsson et al. studied the adsorption of lysozyme and ovalbumin on metal surfaces by ellipsometric and capacitance measurements [6]. With these two techniques it was possible to get information on the protein-metal interaction as well as on the conformation of adsorbed protein. It was seen that lysozyme adsorbs in a two-layer structure, whereas a monolayer structure was found for ovalbumin; evidence was given on the contribution of the electrostatic interaction between the proteins and the metal to the protein adsorption. 
Protein adsorption on gold surfaces under applied potential is a promising way to control the amount and orientation of the immobilized molecules. Proteins in solution with $\mathrm{pH}$ different from the isoelectric point (pI) will be positively or negatively net charged. Due to the electrostatic interaction, protein adsorption on charged surfaces will be different. Until now there have been only a few reports on protein adsorption onto solid surfaces under applied potential. Bernabeu and Caprani [19] studied the adsorption of fibrinogen and albumin onto the surface of a carbon electrode when both proteins were negatively charged. It was found that the amount of protein adsorbed onto the electrode surface increased with increasing negative charge of the surface. It was proposed that cations from the solvent adsorbed onto the electrode surface created a positively charged layer with which the proteins could interact. Brusatori [20] investigated the adsorption of several proteins on indium tin oxidecoated electrodes under an electric field $(0-2.0 \mathrm{~V})$. The results showed that the adsorption amount was improved by applied potential for the three proteins tested (albumin, apotransferrin, cytochrome c). Investigation of human serum albumin and immunoglobulin $\mathrm{G}$ on gold electrodes with radiolabeling and electrochemistry showed that the amount of adsorbed protein increased under positive applied potential and decreased under negative [21].

The purpose of this work is to investigate human serum albumin adsorption on gold surfaces using the combined techniques of ellipsometry and electrochemistry.

\section{Experimental}

\subsection{Substrates}

Gold substrates were prepared by the vapor deposition of $100 \mathrm{~nm}$ of gold onto chrome $(1 \mathrm{~nm})$ predeposited silicon substrates. The gold was shown to be polycrystal-like on the silicon surface and the gold aggregates have a size of about $50 \mathrm{~nm}$ (observed by AFM). Gold slides were cut to be $1.3 \times$ $1.3 \mathrm{~cm}^{2}$, washed with piranha solution $\left(\mathrm{H}_{2} \mathrm{SO}_{4}: \mathrm{H}_{2} \mathrm{O}_{2}=3: 1\right.$, $\mathrm{v} / \mathrm{v}$ ) for $1 \mathrm{~min}$, and then washed with water and ethanol and measured with ellipsometry to ensure that the surface is thoroughly cleaned.

\subsection{Proteins and chemicals}

Human serum albumin (A3782, purity 99\%) was purchased from Sigma and used as received. The proteins were diluted with PBS buffer $\left(8 \mathrm{mM} \mathrm{Na} 2 \mathrm{PO}_{4} \cdot 2 \mathrm{H}_{2} \mathrm{O}, 2.68 \mathrm{mM}\right.$ $\mathrm{KCl}, 1.14 \mathrm{mM} \mathrm{KH}_{2} \mathrm{PO}_{4}, 137 \mathrm{mM} \mathrm{NaCl} ; \mathrm{pH} 7.4$ ) to give a concentration of $0.1 \mathrm{mg} / \mathrm{ml}$. In experiments where gold substrate was incubated in PBS for some time and then the albumin was added to the PBS, the stock albumin $(10 \mathrm{mg} / \mathrm{ml})$ was used in order to give a final concentration of $0.1 \mathrm{mg} / \mathrm{ml}$. Other chemicals used are all products of analytical grade.

\subsection{Ellipsometry}

Ellipsometry is based on measuring the change of the state polarization of elliptically polarized light when it is reflected at a surface. From the changes in the ellipsometric angles $(\Delta, \Psi)$, the refractive index and the thickness of the film can be deduced [11].

The optical characterization of the gold substrates before and after protein adsorption was done with an ellipsometer (SENTECH Instruments $\mathrm{GmbH}$, Berlin) fitted with a $\mathrm{He}-\mathrm{Ne}$ laser $(632.8 \mathrm{~nm})$. The data were processed and fitted using the software provided by SENTECH (SE 400). This ellipsometer was also employed to measure the in situ adsorption of protein, with or without applied potential, an especially designed electrochemical cell fitted with optical glass windows being used.

Compared with other methods, ellipsometry has the advantage of not involving any labeling and it can also be used combined with electrochemistry to characterize electrode surfaces [22].

\subsection{Electrochemistry}

A three-electrode Teflon cell was employed to perform the electrochemical experiments with the gold working electrode fixed to the bottom of the cell by an O-ring. The geometric area of the working electrode was defined to be $0.60 \mathrm{~cm}^{2}$. A saturated calomel electrode (SCE) and a platinum foil served as the reference electrode and the counterelectrode, respectively.

The experiments to record the optical parameters under controlled potential were carried out with the abovementioned electrochemical cell fitted with optical glass windows. A platinum gauze counterelectrode, a saturated calomel reference electrode, and an EG\&G Bi-potentiostat (Model 366) were used for the electrochemical characterization. The gold substrates were clamped against a Teflon O-ring, which defined the geometric area of the working electrode $\left(0.2 \mathrm{~cm}^{2}\right)$.

\section{Results and discussion}

\subsection{Albumin adsorption on gold}

Fig. 1 shows the open-circuit potential of the gold surface in PBS buffer. As soon as the gold surface contacted the PBS solution an electrical double layer formed on the surface and the open circuit potential (OCP) of the gold decreased quickly until the potential reached a stable value of about $100 \mathrm{mV}$ after about $1200 \mathrm{~s}$. This decrease of OCP before reaching a plateau has been observed for all of the electrodes tested $(>10)$, with a sample-to-sample variability of $\pm 30 \mathrm{mV}$. The variability was attributed to subtle differences in the gold surfaces (e.g., defects and contaminants). When albumin was added to the PBS solution, its adsorption 


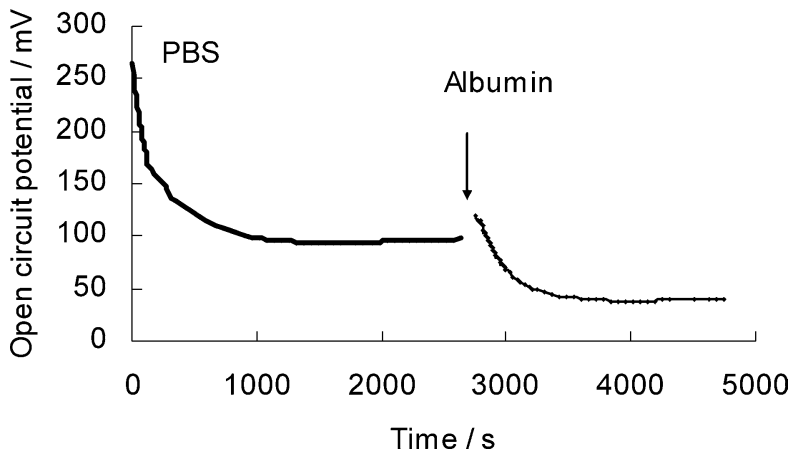

Fig. 1. Open-circuit potential of gold surface in PBS and albumin solution. Albumin concentration: $0.1 \mathrm{mg} / \mathrm{ml}$.
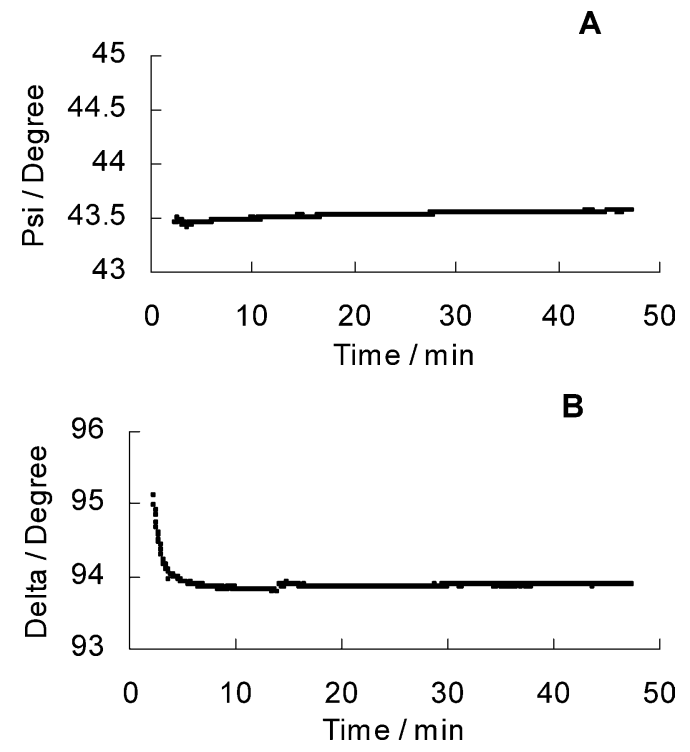

Fig. 2. Changes in the ellipsometric parameters of gold surface during the adsorption of albumin $(0.1 \mathrm{mg} / \mathrm{ml}$ in PBS).

also caused a decrease of the potential. After approximately $900 \mathrm{~s}$ a potential plateau was reached at about $40-60 \mathrm{mV}$.

Ex situ ellipsometry (in air) was used to measure the changes in optical parameters of the gold surface with adsorbed albumin. The results showed that there is a small increase in $\Psi$ and a significant decrease in $\Delta$, which agrees with the presence of a thin nearly transparent layer, as expected for the formation of a protein layer. According to the optical parameters of the gold surface before and after protein adsorption $(\delta \Psi=0.009$ and $\delta \Delta=-1.642)$, the albumin layer thickness was estimated to be about $1.5 \mathrm{~nm}$ (with an error of $0.1 \mathrm{~nm}$ ). The thickness values were calculated using the SE 400 software for a three-layer model taking the real part of the refractive index as 1.48 [23] and the extinction coefficient $(k)$ was estimated to be nearly zero.

Changes of the ellipsometric parameters of the gold surface during the adsorption of albumin were measured and are shown in Fig. 2A and 2B. With the adsorption of protein on the gold surface, the value of $\Delta$ decreased until a plateau was reached in about $10 \mathrm{~min}$. Since protein adsorption layer was transparent or nearly transparent, the adsorption of albumin caused little change of $\Psi$ (Fig. 2A). The protein thickness measured in air after the adsorption was again $1.5 \mathrm{~nm}$.

The accepted size of the human serum albumin molecule is $3 \times 8 \times 8 \mathrm{~nm}^{3}$ [24]. Thus, for the side-on position, one molecule occupies $8 \times 8 \mathrm{~nm}^{2}$, while the end-on position requires $3 \times 8 \mathrm{~nm}^{2}$. Without considering any conformational arrangement, the surface concentration corresponding to the protein close-packed adsorption layer can be calculated accordingly and gives 0.17 and $0.48 \mu \mathrm{g} / \mathrm{cm}^{2}$ for side-on and end-on positions, respectively. In this work, the surface concentration of albumin corresponding to the adsorption layer thickness was estimated using the relationship

surface concentration $\left(\mu \mathrm{g} / \mathrm{cm}^{2}\right) \approx$ density $\times$ thickness $(\mathrm{nm})$,

where the density of the protein was taken as $1.36 \mathrm{~g} / \mathrm{ml}$ [12]. The thus evaluated surface concentration of albumin on gold surface is $0.2 \mu \mathrm{g} / \mathrm{cm}^{2}$, which is slightly higher than the value expected for a close-packed side-on position. This result suggests that the protein molecules do not all adsorb in the side-on position, it being plausible that some are adsorbed in end-on or overlap positions. It is also worth while to stress that proteins conformational changes may also occur turning difficult to ascertain from the molecular dimensions the exact adsorption position at the electrode surface.

\subsection{Albumin adsorption under applied potential}

The effect of potential on the albumin adsorption on gold surface was investigated by ellipsometry. The cell was filled with PBS solution, a constant potential was applied to the gold surface, and then albumin was added. Figs. 3A and 3B show the changes of the ellipsometric parameters of the gold surface during the adsorption of albumin under $200 \mathrm{mV}$. As previously observed, upon protein addition the value of $\Delta$ decreased until a plateau was reached. The adsorption of albumin under applied potential also caused little change of $\Psi$, which is consistent with the formation of a thin nearly transparent layer. The protein layer thicknesses measured in air after adsorption under different applied potentials are shown in Table 1. An increase of thickness from 1.5 to 2 (at $100 \mathrm{mV}$ and $-100 \mathrm{mV}$ ) and to $2.4 \mathrm{~nm}$ (at $200 \mathrm{mV}$ ) can be observed. The results strongly indicate that albumin adsorption can be promoted under both positive and negative applied potentials.

It is widely accepted that the protein adsorption process involves protein transport (diffusion) from the bulk solution to the surface, its adsorption onto the surface, protein conformational changes or orientation to a more stable position on the surface, and protein desorption to the bulk solution (Fig. 4A). When protein is in a solution with a $\mathrm{pH}$ higher than its isoelectric point (pI), such as albumin (pI 4.7) in PBS buffer ( $\mathrm{pH}$ 7.4), the protein will present a net negative charge. When the surface is subjected to positive potentials, more binding sites are supplied, resulting in an increase of protein adsorption (Fig. 4B). On the other hand, due to the 
gathering of the counterions, a negatively polarized surface can also attract proteins; if the protein conformation is not stable, it can be modified so that positively charged domains
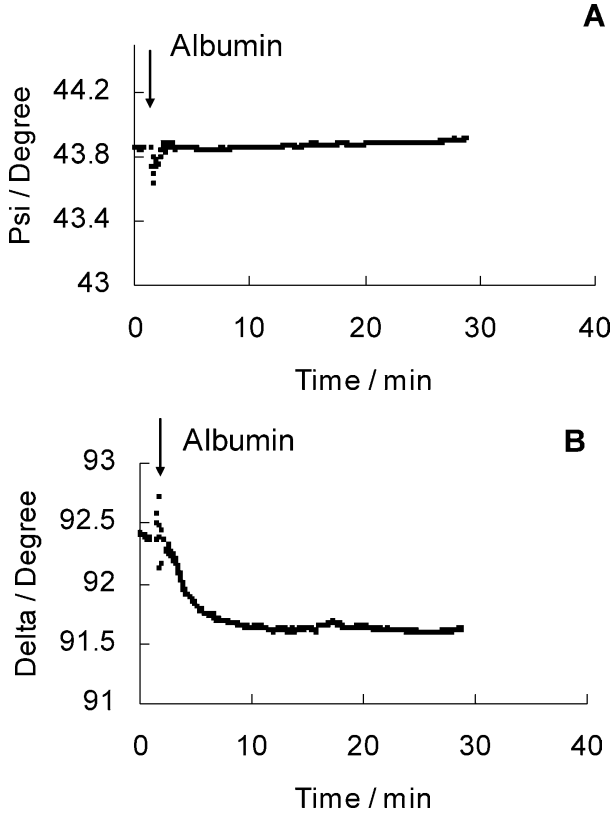

Fig. 3. Changes in the ellipsometric parameters of gold surface during the adsorption of albumin under applied potential $(200 \mathrm{mV})$. The arrows show albumin addition to the cell (after stable optical parameters of gold surface in PBS are observed under the applied potential).

Table 1

Albumin adsorption layer thicknesses at different applied potentials

\begin{tabular}{lllll}
\hline Potential applied $(\mathrm{mV})$ & -100 & 0 & 100 & 200
\end{tabular}

\begin{tabular}{lllll} 
Protein adsorption layer thickness $( \pm 0.2 \mathrm{~nm})$ & 2.0 & 1.5 & 2.0 & 2.4 \\
\hline
\end{tabular}

come into contact with the surface, allowing steady adsorption (Fig. 4C). However, for rigid protein structures, i.e., when the conformation cannot be changed easily, applying negative potential cannot promote protein adsorption. Albumin being a flexible protein displaying an easily changeable conformation upon adsorption $[25,26]$, the expected effect of negative surface polarization is the promotion of protein adsorption, as observed.

\subsection{Stability of adsorbed albumin under applied potential}

In order to investigate the stability of the modified gold surface with albumin (30 min incubation) under applied potential, optical parameters were measured in situ while an external electric signal was applied to the gold surface. As the potential was swept from -200 to $600 \mathrm{mV}$, both $\Psi$ and $\Delta$ showed reversible changes (Figs. 5A and 5B) during several potential cycles, revealing that the protein layer presents good stability in this potential range.

The observed effect of applied potential on the optical properties of gold with adsorbed albumin was seen to be similar to that displayed by the bare gold surface. Thus, the modifications of the ellipsometric parameters should be attributed mainly to changes on the background substrate rather than on the adsorption layer. The role of the gold substrate can also be retrieved from the current responses presented in Fig. 5C. The similarity of the cyclic voltammograms recorded for modified gold with albumin and the bare gold supports that gold oxidation can proceed underneath the adsorption layer; the data reproducibility under repetitive potential cycling reinforces the stability of the albumin layer even in the potential region where gold oxide starts to be formed.

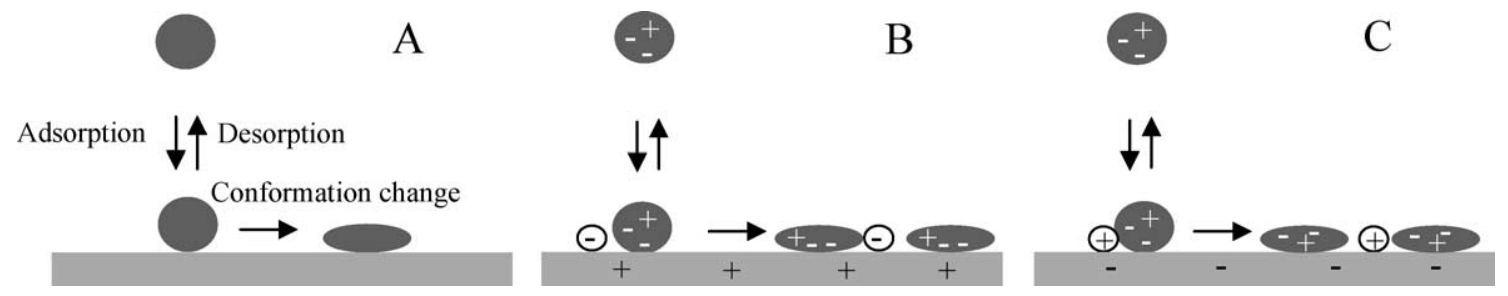

Fig. 4. Models for protein adsorption onto (A) uncharged surface; (B) positively charged surface; (C) negatively charged surface.
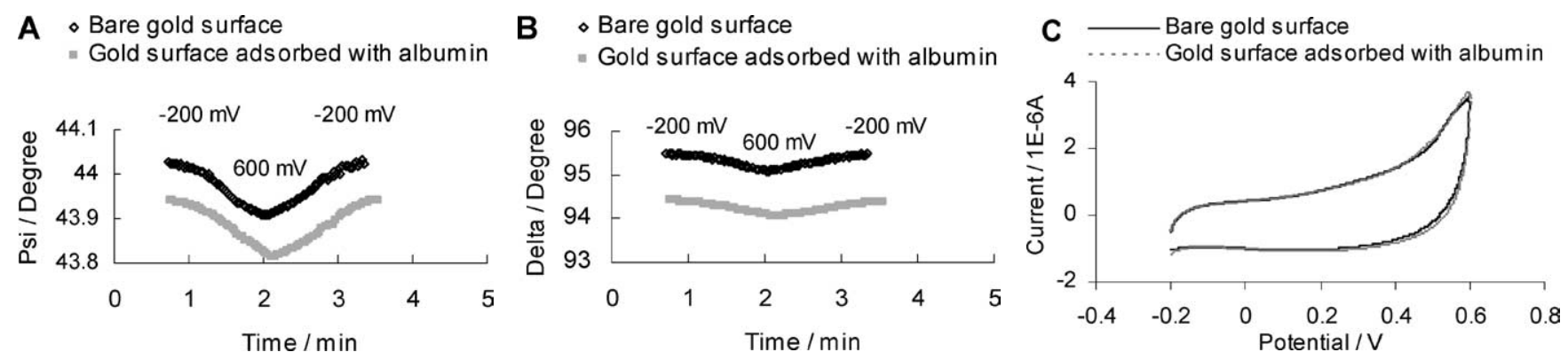

Fig. 5. Optical parameter variation with potential (A, B) and cyclic voltammograms (C) of gold with and without albumin adsorption layer in PBS (bare gold surface) and PBS containing $0.1 \mathrm{mg} / \mathrm{ml}$ albumin (gold surface with adsorbed albumin. Potential scan rate: $50 \mathrm{mV} / \mathrm{s}$. 


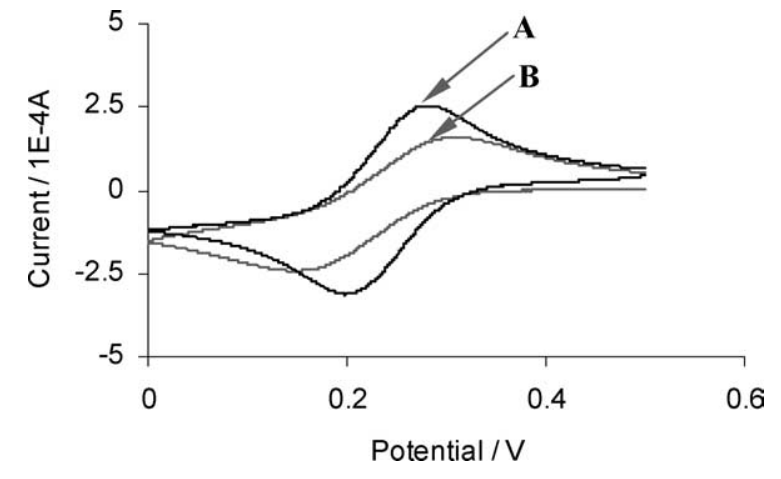

Fig. 6. Cyclic voltammograms at bare gold surface (A) and gold surface modified with albumin (B) in $\mathrm{K}_{3} \mathrm{Fe}(\mathrm{CN})_{6} 10 \mathrm{mM}+\mathrm{KNO}_{3} 1 \mathrm{M}$. Potential scan rate: $10 \mathrm{mV} / \mathrm{s}$.

The electrochemical behavior of the gold surface modified with albumin was further tested toward the redox behavior of $\mathrm{K}_{3} \mathrm{Fe}(\mathrm{CN})_{6}$ solutions. As depicted in Fig. 6, the reduction and oxidation processes of $\mathrm{K}_{3} \mathrm{Fe}(\mathrm{CN})_{6}$ are well detectable on both bare and modified gold surfaces, but in the latter case the peak currents are considerably smaller (about $40 \%$ ) than on the bare gold, as a result of the expected blocking properties of the albumin adsorption layer.

\section{Conclusions}

The incubation of a gold surface in albumin solution causes a decrease in the substrate open-circuit potential and eventually a potential plateau is reached. The concomitant variation of the ellipsometric parameters (small increase of $\Psi$ and significant decrease of $\Delta$ ) has confirmed gold modification with the albumin layer, with a thickness of approximately $1.5 \mathrm{~nm}$. The application of both positive (100, $200 \mathrm{mV})$ and negative $(-100 \mathrm{mV})$ potentials promotes the albumin adsorption on gold surfaces, indicating the flexibility and ability of the protein to change its conformation on the surface. In spite of presenting no effect on the gold response in PBS, as revealed by cyclic voltammetry, the immobilized albumin has remarkable stability on the surface within the potential range from -200 to $600 \mathrm{mV}$, as confirmed by the reversible changes of the optical and electrochemical parameters upon repetitive potential cycling. Evidence is given for the blocking properties of the albumin adsorption layer on gold through the marked decrease in the peak current (40\%) observed when the current responses of bare and modified surfaces toward the redox conversion of $\mathrm{K}_{3} \mathrm{Fe}(\mathrm{CN})_{6}$ are contrasted.

\section{Acknowledgments}

The Chinese Academy of Sciences, the National Natural Science Foundation of China, and the Fourth ChinaPortugal Joint Commission Meeting for S\&T Cooperation of 2001-2003 are gratefully acknowledged for their support.

\section{References}

[1] T.A. Horbett, J.L. Brash, in: J.L. Brash, T.A. Horbett (Eds.), Proteins at Interfaces, Physicochemical and Biochemical Studies, American Chemical Society, Washington, DC, 1987.

[2] J.L. Brash, T.A. Horbett, in: T.A. Horbett, J.L. Brash (Eds.), Proteins at Interfaces: II. Fundamentals and Applications, American Chemical Society, Washington, DC, 1994.

[3] B. Montdargent, D. Letourneur, Infect. Control Hosp. Epidemiol. 21 (2000) 404.

[4] J.L. Dewez, A. Doren, Y.J. Schneider, P.G. Rouxhet, Biomaterials 20 (1999) 547.

[5] C. Combes, C. Rey, Biomaterials 23 (2002) 2817.

[6] B.A. Ivarsson, P.-O. Hegg, K.I. Lundstrom, U. Jonsson, Colloids Surf. 13 (1985) 169.

[7] D.F. Williams, I.N. Askill, R. Smith, J. Biomed. Mater. Res. 19 (1985) 313.

[8] B. Ivarsson, I. Lundstrom, Crit. Rev. Biocompat. 2 (1986) 1.

[9] R.L. Williams, D.F. Williams, Biomaterials 9 (1988) 206.

[10] G.T. Tayler, P.J. Troy, S.K. Sharma, Mar. Chem. 45 (1994) 15.

[11] R.M.A. Azzam, N.M. Bashara, Ellipsometry and Polarized Light, North-Holland, Amsterdam, 1987.

[12] H. Elwing, Biomaterials 19 (1998) 397.

[13] U. Jonsson, M. Malmqvist, I. Ronnberg, J. Colloid Interface Sci. 103 (1985) 360 .

[14] J. Benesch, A. Askendal, P. Tengvall, Colloids Surf. B 18 (2000) 71.

[15] P. Schaaf, P. Dejardin, A. Schmitt, Langmuir 3 (1987) 1131.

[16] P. Schaaf, P. Dejardin, A. Schmitt, Rev. Phys. Appl. 21 (1986) 741.

[17] D.J. Sbrich, R.E. Imhof, in: J.R. Lakowicz (Ed.), Topics in Fluorescence Spectroscopy, Plenum, New York, 1991.

[18] J.N. Lin, B. Drake, A.S. Lea, P.K. Hansma, J.D. Andrade, Langmuir 6 (1990) 509.

[19] P. Bernabeu, A. Caprani, Biomaterials 11 (1990) 258.

[20] M.A. Brusatori, Ph.D. thesis, Protein adsorption kinetics under an applied electric field: an optical waveguide lightmode spectroscopy study, Wayne State University, 2001.

[21] S.E. Moulton, J.N. Barisci, A. Bath, R. Stella, G.G. Wallace, J. Colloid Interface Sci. 261 (2003) 312.

[22] A. Hamnett, J. Chem. Soc. Faraday Trans. 89 (1993) 1593.

[23] H. Arwin, Appl. Spectrosc. 40 (1986) 313.

[24] X.M. He, D.C. Carter, Nature 358 (1992) 209.

[25] E.J. Castillo, J.L. Koenig, J.M. Anderson, Biomaterials 5 (1984) 319.

[26] W. Norde, Adv. Colloid Interface Sci. 25 (1986) 267. 